\title{
SIXTEENTH CENTURY STOVE TILES FROM THE MAIN SQUARE OF PÁPA, WESTERN HUNGARY
}

\author{
ÁGNES KOLLÁTH
}

\author{
Hungarian Academy of Sciences \\ Research Centre for Humanities \\ Archaeological Institute \\ Úri u. 49, H-1014, Budapest, Hungary \\ kollath.agnes@btk.mta.hu
}

\begin{abstract}
Stove tile fragments came to light during the excavations at the Main Square (Fö tér) in the town of Pápa (HU, Veszprém County) from a closed find assemblage dated to the $16^{\text {th }}$ century. Their decoration could be identified as biblical and profane scenes. This article is aimed examining the origins and connections of these good quality pieces and their historical context at the beginning of the age of Reformation.
\end{abstract}

Keywords: Pápa-Fö tér, stove tiles, biblical scenes, $16^{\text {th }}$ century

THE SITE

The Main Square (Fö tér) at Pápa, a medieval market town in the middle region of the Hungarian Transdanubia (Fig. 1), underwent major reconstruction during the past few years that had been preceded by archaeological research in 2010 and 2011. ${ }^{1}$ These works have brought to light a large amount of objects dated from the early $10^{\text {th }}$ century period of the Árpád Dynasty to the $20^{\text {th }}$ century and some stray finds from the Prehistoric, Roman and Migration Periods. Thanks to the quite large area (more than $2000 \mathrm{~m}^{2}$ ) excavated the development of the city centre could be followed from its foundation in the $10^{\text {th }}$ century until the late $18^{\text {th }}$ century rearrangement, when the square had gained its present day appearance. ${ }^{2}$

The earliest finds were the traces of a rural settlement that existed in this territory from the turn of $10^{\text {th }}-11^{\text {th }}$ centuries till the end of the $13^{\text {th }}$ century. According to written sources and archaeological finds, the site had been systematically demolished, filled up and levelled at the beginning of the $14^{\text {th }}$ century at the latest, to create a foundation for the pavement of the newly established market place. The church built in the middle of the square, was initially surrounded by a wide, deep trench and a massive wooden palisade. As the importance of the market and transit traffic grew, these features had been deemed unnecessary and a less significant fence was built, closer to the church. ${ }^{3}$ This had resulted in the reduction of the cemetery grounds. Consequently, we found a very concentrated graveyard, with multiply superpositioned burials dated from the Árpádian Period till the end of the $18^{\text {th }}$ century. ${ }^{4}$ The church itself was dedicated to St. Stephen but we could not find any trace of its earliest form. It had been rebuilt in late Gothic style in the $15^{\text {th }}$ century and demolished in the $18^{\text {th }}$ century, when the now existing baroque building was erected. ${ }^{5}$

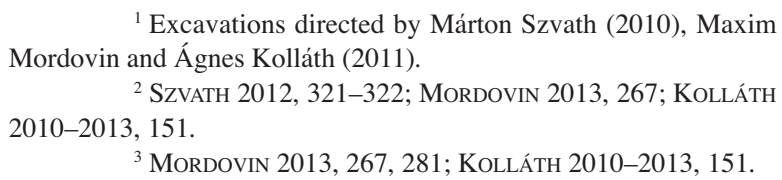

${ }^{1}$ Excavations directed by Márton Szvath (2010), Maxim Mordovin and Ágnes Kolláth (2011).

${ }^{2}$ SZVATH 2012, 321-322; MoRdovin 2013, 267; KolLÁTH 2010-2013, 151

${ }^{3}$ MoRdovin 2013, 267, 281; KolLÁTH 2010-2013, 151

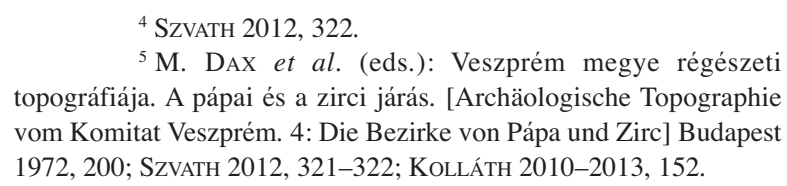

${ }^{5} \mathrm{M}$. DAX et al. (eds.): Veszprém megye régészeti topográfiája. A pápai és a zirci járás. [Archäologische Topographie vom Komitat Veszprém. 4: Die Bezirke von Pápa und Zirc] Budapest 1972, 200; SzVATH 2012, 321-322; Kolláth 2010-2013, 152. 


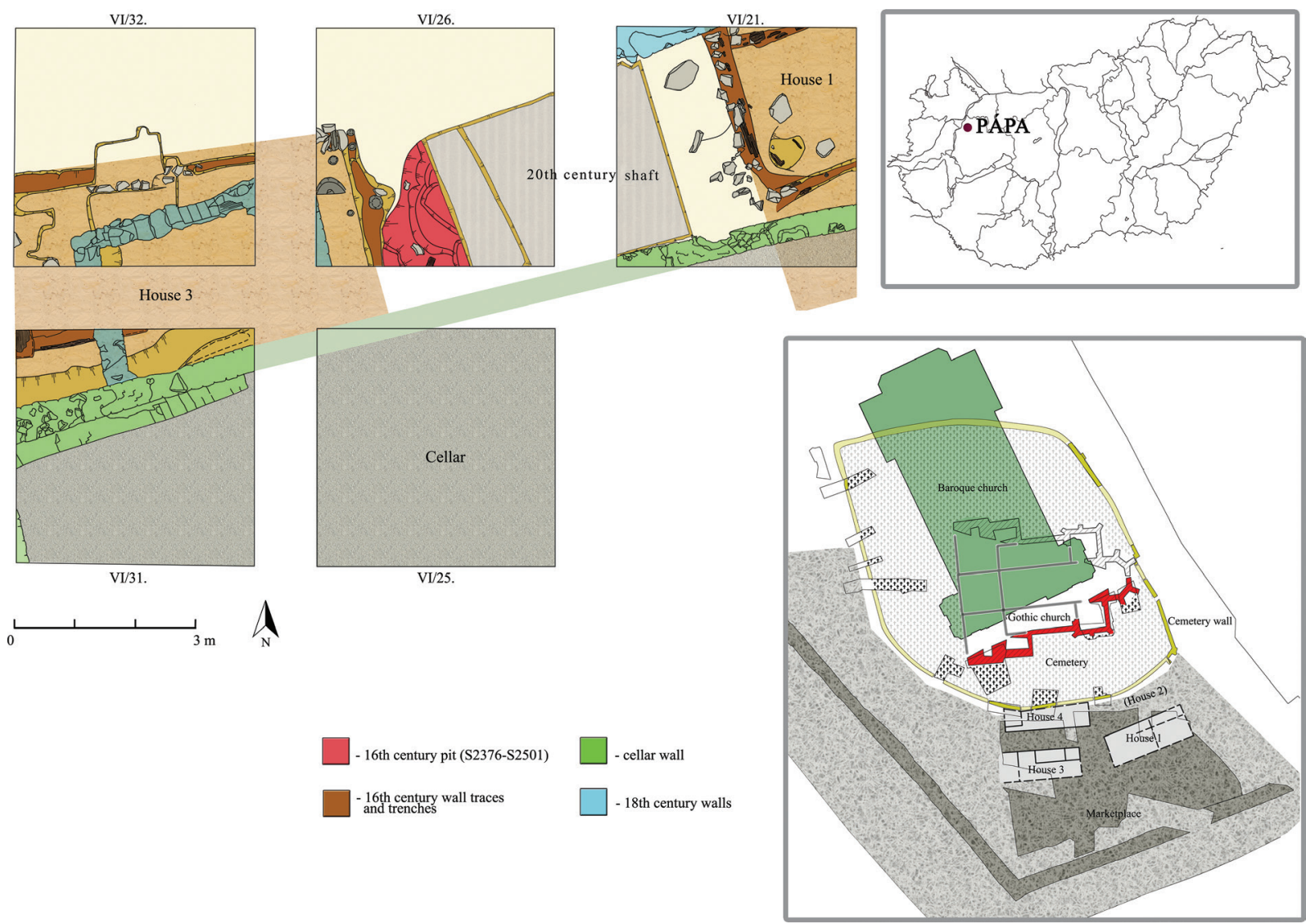

Fig.1. The situation of Pápa, the archaeological objects of the $16^{\text {th }}$ century Main Square and the ground plan of the tiles' find place

The periodical renewal of the square's surface could be traced from its earliest phase till the last, $20^{\text {th }}$ century asphalt pavement. Its area has decreased in the middle of the $16^{\text {th }}$ century. ${ }^{6}$ After the battle of Mohács and the death of King Louis II (1526) the war between the two new rulers (John I of Szapolya and Ferdinand Habsburg I) and the Ottoman armies intensified. The castle and market town of Pápa was fortified and manned by a considerable garrison by then, thus many people, inhabitants of the nearby villages and nobility from the neighbouring land have moved in. ${ }^{7}$ Some of the new houses were built in the north eastern part of the Main Square, near the church fence. We could identify four buildings that were all Fachwerk-constructions, made of timber, stone and clay. Their ground level had probably served as shops, because we found large quantities of animal bones stamped in the surface, furthermore many coins and cloth seals, all datable to this period. ${ }^{8}$

This was a very vivid period in the settlement's life, but the turmoil of the $16^{\text {th }}$ century, with the wars tearing the Hungarian Kingdom in three parts, did not evade Pápa for long. In 1594 its garrison abandoned the town, as they have heard, that the important nearby fortress of Györ had been lost to the Ottomans. The Tartar auxiliaries of the Sultan's army have arrived first and they have captured the city without siege. Although it was taken back three years later by Christian troops, they needed to use bombarding and stored gunpowder also exploded. According to the sources, most of the buildings were destroyed, but this was not the last catastrophe. The newly posted Christian defence force, mostly Walloonian mercenaries, did not get their salary and could not find enough food in the burnt out vicinity of the town, so they have started to revolt. The armies of the Habsburg Emperor had to take back the city again by siege. ${ }^{9}$

\footnotetext{
${ }^{6}$ Mordovin 2013, 281.

${ }^{7}$ SZAKÁLY 1994, 78.
} 153, Fig. 1

${ }^{8}$ Mordovin 2013, 267; 269, Fig. 1; Kolláth 2010-2013, 
The new houses in the Main Square burnt down probably in one of these conflicts or perhaps in the numerous fires mentioned at the beginning of the $17^{\text {th }}$ century. ${ }^{10}$ We could observe an intense, red burnt demolition-layer in their locality, with traces of the collapsed clay walls and wooden partitions, in addition to the charred remains of the timber beams. Afterwards the ruins had been levelled and new buildings were erected with mortared stone walls. ${ }^{11}$ Two of them were built exactly on the same spot as their predecessors, ${ }^{12}$ but the southern house-row was replaced at some point after 1626 by the massive cellar of the Esterházy family, who became the owners of the town by then. ${ }^{13}$ Because of this extensive building activity we could find only fragments of the $16^{\text {th }}$ century buildings, but luckily the remaining parts and rich find material allow us a glimpse on the everyday life of this contradictory era. The objects described in this article help to get a closer look not just at the connections of the citizens of Pápa, but also at the artistic and religious influences, that could reach them.

\section{THE FIND CONTEXT}

Twelve of the stove tile fragments were found in a roughly round, $180 \mathrm{~cm}$ deep pit of circa $100 \times 150 \mathrm{~cm}$ between two of the $16^{\text {th }}$ century houses (House 1 and 3) in the southern row (Fig. 2-3). There was a strongly burnt clay layer with much charcoal on its top, which covered the whole area of the excavation sector. Underneath was a fill layer with clay and mortar crumbs, also in the pit and its surroundings. ${ }^{14}$ This was followed by another burnt, ashy layer with charred remains of wooden beams. This has not exceeded outside of the pit. The bottom of the object has contained a brownish grey, ashy clay layer with some pieces of sack cloth in it. It is possible, that the pit was opened previously in the $16^{\text {th }}$ century, as it did not hold earlier finds, but it seems to be quite sure, that it was filled up and levelled with the remains of the burnt down features of the marketplace by the beginning of the 1600's at the latest. Unfortunately its eastern side was destroyed by a $20^{\text {th }}$ century shaft (S2175) and we have not had the opportunity to fully excavate its southern rim either. Moreover, the latter part of the feature had probably been damaged earlier by the building or the destruction of the Esterházy-cellar in the $17^{\text {th }}-18^{\text {th }}$ centuries. This disturbance is shown by the location of the two remaining tile-fragments in the eastern neighbouring sector, amidst the fill of the demolished, large stone-brick structure (S2125). ${ }^{15}$

These circumstances partly explain, why we could find so few stove tiles in the $16^{\text {th }}$ century layers, but their overall number in the whole excavation was likewise small. As the known pieces have not been seriously burnt in the flames that destroyed the houses, it is possible, that the intact tiles were collected and used elsewhere during the rebuilding of the town. The original location of the stove or rather stoves could equally be in House 1 or House 3 as the pit was dug between them, but we could not find their bases or other remains. Therefore it is less probable, but not impossible that they belonged to a third, unknown building.

\section{THE STOVE TILES ${ }^{16}$}

\section{Group 1 (Cat. Nos. 1-3; Figs. 9-11)}

Material and base form: Seven unglazed fragments belong here. They were fired in reducing atmosphere, their material is grey on the outside, lighter, yellowish grey on the fractures. They contain some small, white and brown inclusions and a little mica. They are square shaped, panel tiles with short thrown body. ${ }^{17}$ They have oblique walls, probably also made for use on corners, as part of a wide, oblong opening is visible on one fragment's back

\footnotetext{
${ }^{10}$ SZAKÁly 1994, 83.

${ }^{11}$ KolLáth 2010-2013, 152-153; 153, Fig. 1.

${ }^{12}$ Because of this and the $20^{\text {th }}$ century building activities we could securely identify the traces of House 2 only in the profile walls. Therefore its ground plan is not shown on Fig. 1.

${ }^{13}$ SZAKÁly 1994, 83.

${ }^{14}$ The stratigraphy of these sectors usually started under the asphalt pavement and road-foundation with the $16^{\text {th }}$ century layers,
}

as the younger phenomena had been removed by levelling works in the $20^{\text {th }}$ century.

${ }^{15}$ These two frame-fragments are unfortunately not accessible in the Museum of Pápa at the moment. They are known from the photos taken during the excavation.

${ }^{16}$ I would like to thank hereby Edit Kocsis for her valuable advice concerning the tiles.

${ }^{17}$ Roth Heege 2012, 271. 
Pápa-Fö tér, surface VI, section 26

Southern profile

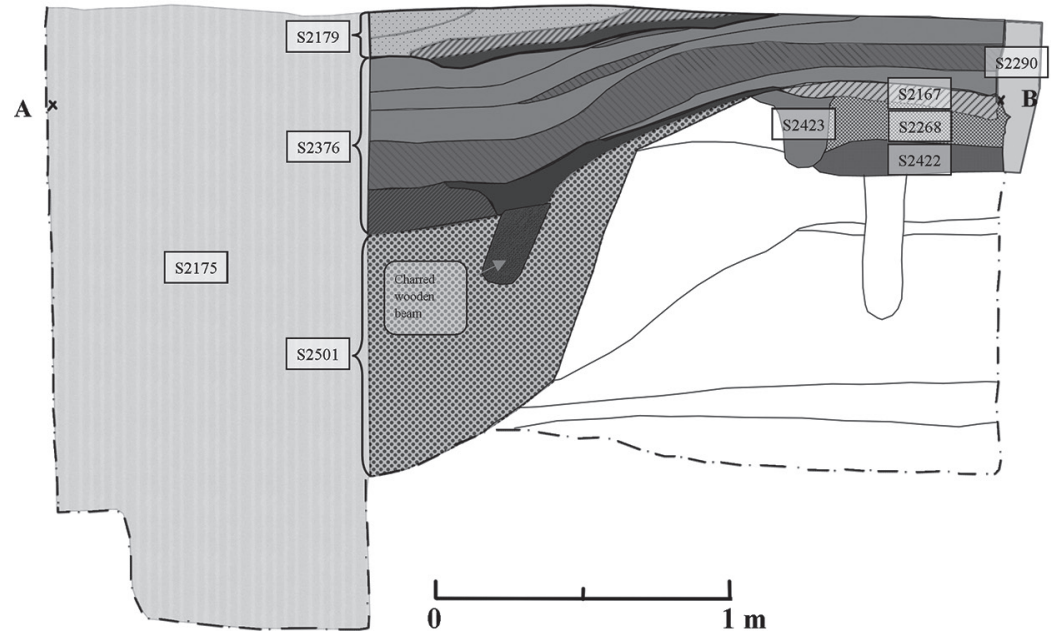

LEGEND

$\mathrm{S} 2167=16^{\text {th }}$ century burnt demolition layer

$\mathrm{S} 2175=20^{\text {th }}$ century shaft

S2179 = uppermost, disturbed part of the $16^{\text {th }}$ century planing layers

$\mathrm{S} 2268=16^{\text {th }}$ century fill layer

$\mathrm{S} 2290=18^{\text {th }}$ century wall

S2376 = planing layers of the demolished $16^{\text {th }}$ century period

S2422 = clay floor of the $16^{\text {th }}$ century house

S2423 = wall trench of the $16^{\text {th }}$ century house

$\mathrm{S} 2501=16^{\text {th }}$ century pit

Fig. 2. Profile drawing of the pit (S2179-S2376-S2501), where most of the tile fragments were found

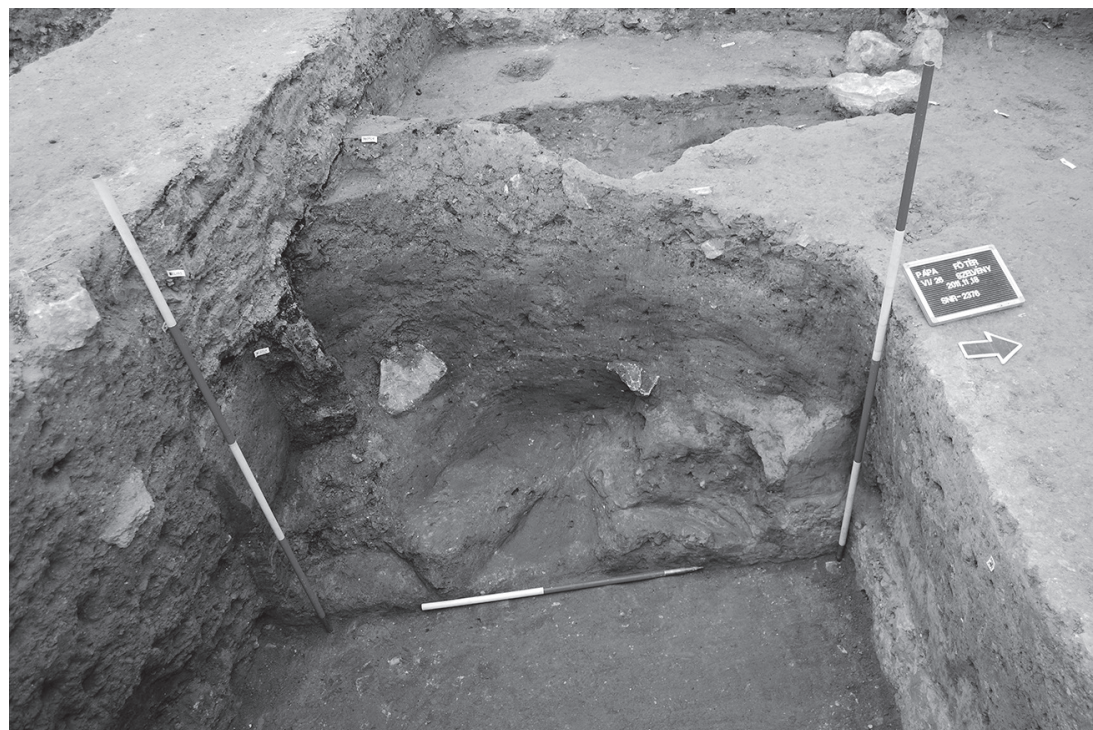

Fig. 3 . The $16^{\text {th }}$ century pit (S2179-S2376-S2501) with charred timber remains, damaged by a 20 ${ }^{\text {th }}$ century shaft (S2175)

rim that makes sense only in this case. As we have two identical parts of the image, it is possible that all of the pieces have belonged to the same, double corner-tile, but as their connection is missing, this remains uncertain. The original dimensions of their front side could be circa 20-25×20-25 cm.

Production and usage traces: The rear wall is perforated on one of the fragments; the hole could serve the more even drying process. (Fig. 4) There are two fragments with the same part of the picture. Their measures are almost completely identical, so it seems that they were made in the same mould. The impression of the textile used by the moulding is clearly visible on the tiles' rear side. All of them are sooty in the inside, which shows that they were in use. (Fig. 5)

Image: The frame is rather simple, profiled; its height shrinks towards the central field. The background is decorated by slightly elevated point-circles. Two stylized flowers can be found in the upper left and the lower right corners of the picture. The central composition, which takes up most of the available space, depicts a bearded 


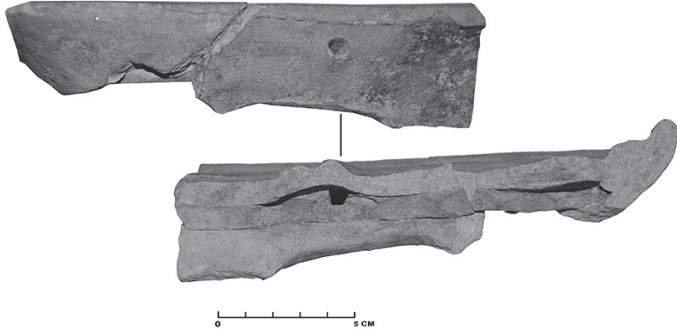

Fig. 4. Cut out and punched through part of the rear wall of Cat. No. 3

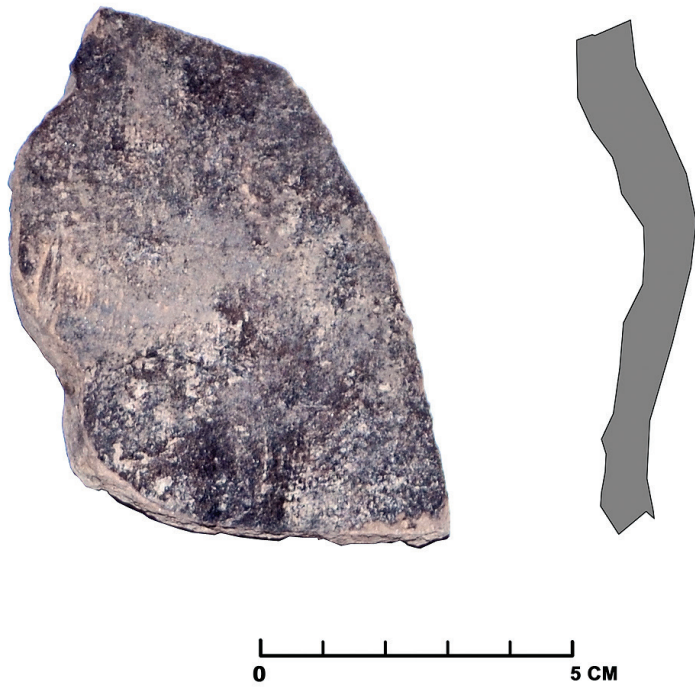

Fig. 5. Textile impression on the back of Cat. No. 1

man in a long sleeved jacket with ruffled cuffs, opening the mouth of a lion. The lion's tongue is visible, as well as a shoed foot with a spur at the middle-right edge of the picture field. There is also a tendril-like shape above the man's head, which can be part of a feathered hat or the hair of the main character. Although relatively large pieces are missing, it seems that the hero was kneeling on the back of the beast (which explains the shoe at the middle-right edge) pushing him to the ground and pulling his head upwards in the same time. (Fig. 6)

Interpretation and parallels: The scene is most likely of Samson's fight with the lion from the Old Testament. ${ }^{18}$ It was quite popular in the Middle Ages, partly because of its symbolic meaning, as Samson's victory could be seen as the antecedent of Christ's triumph on death. ${ }^{19}$ The theme has also appeared early on stove tiles, the first examples are known from the $14^{\text {th }}$ century in Hungary and in the territory of the Czech Republic. Some pieces show the lion's head turned towards Samson, while on another one the hero grasps the jaws of the beast from backwards. ${ }^{20}$ The Pápa-variation follows the latter and its arrangement in general is rather simple, its maker did not use the innovations seen on the $15^{\text {th }}-16^{\text {th }}$ century woodcuts depicting this topic. ${ }^{21}$ The lion has also been modelled in a Gothic, heraldic style. However some details of the picture have been actualised, as the main character wears a contemporary, Renaissance jacket and has a well-trimmed beard. On the earlier stove tiles, Samson was usually depicted in armour or in a $15^{\text {th }}$ century style outfit, with clean-shaven face and long, wavy hair. ${ }^{22}$ This type continued to exist in the $16^{\text {th }}$ century in Transylvania, but another variety appeared there as well, where the hero is bearded and has a contemporary outfit, like on the finds discussed here. ${ }^{23}$ The lack of parallels from closer locations can be probably explained by the relatively small number of publications concerning $16^{\text {th }}$ century stove tiles in the Transdanubian region of the Hungarian Kingdom.

${ }^{18}$ Judges XIV, 5-6.

${ }^{19}$ J. PÁL - E. ÚJVÁRI (eds.): Szimbólumtár. Jelképek, motívumok, témák az egyetemes és a magyar kultúrából [Lexicon of Symbols]. Budapest 1997, 356.

${ }^{20}$ I. HoLL: Középkori kályhacsempék Magyarországon I. (Mittelalterliche Ofenkacheln in Ungarn I.) BudRég 18 (1958) 216, Abb. 6. I. HoLL: Középkori kályhacsempék Magyarországon IV. (Mittelalterliche Ofenkacheln in Ungarn IV.) ArchÉrt 117 (1990) 70, Abb. 15; 72, Abb. 17. BRYCH 2004, 60-61, Nos. 81-87.
${ }^{21}$ For example: A. Dürer: Samson tötet den Löwen, 149697 (Herzog Anton Ulrich-Museum (Braunschweig, D) Lugt 291291a.) (http://kk.haum-bs.de/?id=a-duerer-ab2-h0252. Downloaded: 12.11.2014.) S. Beham: Samson zerreißt einen jungen Löwen, 1533. (Herzog Anton Ulrich-Museum (Braunschweig, D) Lugt 291-291a.) (http://kk.haum-bs.de/?id=h-s-beham-ab3-h0023-r Downloaded: 12.11.2014.)

${ }^{22}$ Gruia 2009, 98; cat. 107, 111, 142, 253, 303.

${ }^{23}$ Gruia 2009, 99-102; 101, Fig. 4.12; cat. 150, 181, 183 , 199, 209; 100, Fig. 4.11; cat. 125, 127, 145, 187, 213. 
Material and base form: Five fragments of four tiles belong here. They were fired to a light, reddish brown colour. Their material contains a larger amount of mica and fine, brown and white gravel-particles. All of them were covered by white engobe and then a quite good quality, green lead glaze, which has somewhat oxidised. All fragments were parts of rectangle or square shaped panel tiles with short thrown bodies. ${ }^{24}$ Two of them belong to the same object, though their connecting surface is very small. The tiles' rear wall is vertical.

Production and usage traces: There are two fragments with the same part of the picture in this group as well. Their measures are almost completely identical, so it seems that they were made in the same mould (Cat. Nos. 5-6). All pieces are sooty in the inside, which shows that they were in use.

Images: The frame is only visible on one fragment from the upper part of a rectangular shaped tile. Its rim is simple, elevated; the inner frame had an architectural design. This consisted of a multiply partitioned arch ornamented by acanthus leaf- and rosette-motifs, which was almost certainly seated on two columns. (Cat. No. 4) (Fig. 7)

The two neighbouring pieces show the head and torso of a bearded, crowned king grasping his fur collared mantle with one hand, framed by a rectangular structure. A coated, veiled figure on a harnessed mount, holding something swathed in the shroud can be seen by the upper right corner of this structure. (Cat. No. 5)

The right side of the same mounted figure can be observed on another fragment with the detail of some kind of vegetation to the right. (Cat. No. 6) (Fig. 8)

A seated, armoured man can be seen on the last fragment, who lays his head on his hand propped against his knee. The lifted hand and part of the clothing of another man is visible to the right, with a rectangular construction in the background. (Cat. No. 7)

Interpretation and parallels: The frame's architectural design on Cat. No. 4 is very typical on Renaissance era panel tiles, its use can be traced from the $2^{\text {nd }}$ half of the $16^{\text {th }}$ century. ${ }^{25}$ The exact parallel of its decoration is unknown. No floral elements are used on two of the three identified, similar groups present in Hungary, while one type has masks in the upper corners and a fruit-garland under the arch. ${ }^{26}$ The Pápa-piece is closer to the latter, but it is more abstract, its formulation is less like a part of a real building. It is also quite similar to a fragment from Wiener Neustadt-Neunkirchner Tor (A). ${ }^{27}$ Considering the composition-type seen on these parallels, furthermore the identical material and glazing, it is likely that Cat. No. 4 and the Cat. Nos. 5-7 belonged to the same series.

The latter pieces are parts of a tiles' group depicting Jesus Christ's life. The composition of Cat. Nos. 5-6 can be recognised as The Massacre of the Innocents and The Flight to Egypt combined. ${ }^{28}$ In spite of the strongly simplified image, the mounted character can be identified as the Virgin Mary on the run from Bethlehem, sitting on a donkey, holding the baby Jesus. The group's small dimensions and positioning suggests that they are getting away from the location of the main scene. The crowned king in the foreground should be Herod, seated on a throne or standing in front of a building, commanding the killing of the children. The vegetal detail on the right is the top of a palm tree. The merging of these two parts of the story is not unusual in the medieval and Renaissance art. The portraying of Herod with a kind of modified, "exotic" crown and fur-collared mantle is also quite general. ${ }^{29}$ It is remarkable though that Saint Joseph is missing from the Holy Family, as he is normally part of the scene, leading the donkey. A possible explanation is that the mould was put together from two different models and there was not

\footnotetext{
${ }^{24}$ Roth HeEge 2012, 271.

${ }^{25}$ HoLl 1993, 266; BryCh 2004, 225.

${ }^{26}$ Holl 1993, 278; 280, Abb. 49-52; 284-285; 285, Abb.

57; 286, Abb. 59; 289, Abb. 64. Kocsis 2014, 347, Abb. 2.1-2.

${ }^{27}$ K. KÜHTREIBER: Die Funde der Ausgrabungen am Neunkirchner Tor in Wiener Neustadt. Carnuntum 1999 (2000) 96; 181, Taf. 58/A 225.

${ }^{28}$ Matthew II, 13-18.
}

\footnotetext{
${ }^{29}$ For example: Giovanni Angelo Del Maino: Strage degli Innocenti (1519-1524). Originally part of a wooden altarpiece in Tirano, now in the Museum of Fine Arts (Boston, USA).

(http://www.mfa.org/collections/object/massacre-of-theinnocents-with-herod-in-his-court-and-the-flight-into-egypt-57614 Downoladed: 02.12.2014.)

Martino Rota (1515-1583): Strage degli Innocenti. Engraving after Tiziano Vecellio's drawing. Victoria and Albert Museum (London, UK). (http://collections.vam.ac.uk/item/O1153811/massacre-of-the-innocents-print-rota-martino/ Downloaded: 02.12.2014.)
} 


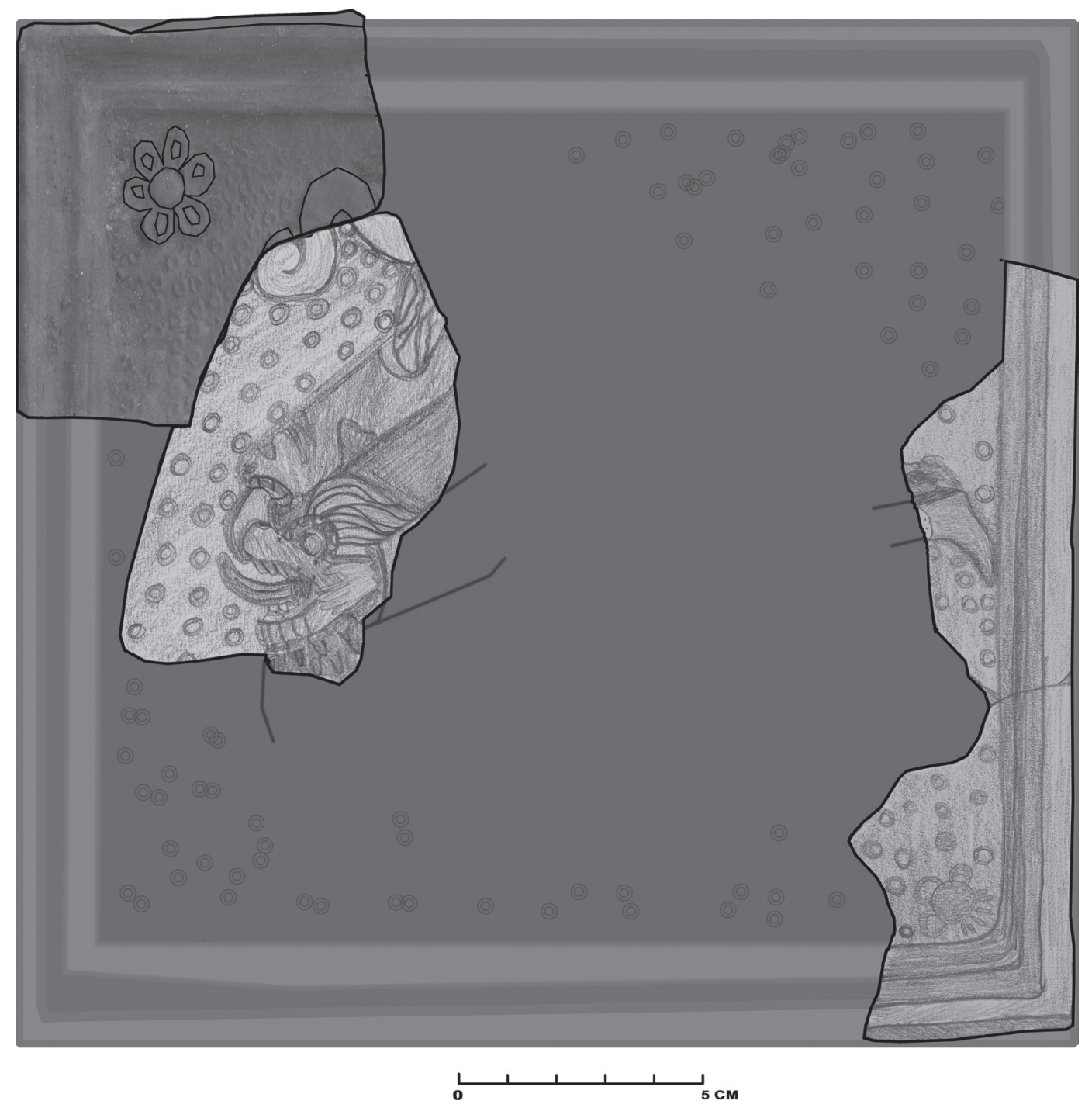

Fig. 6. A part-reconstruction of the Samson-tile of Group 1

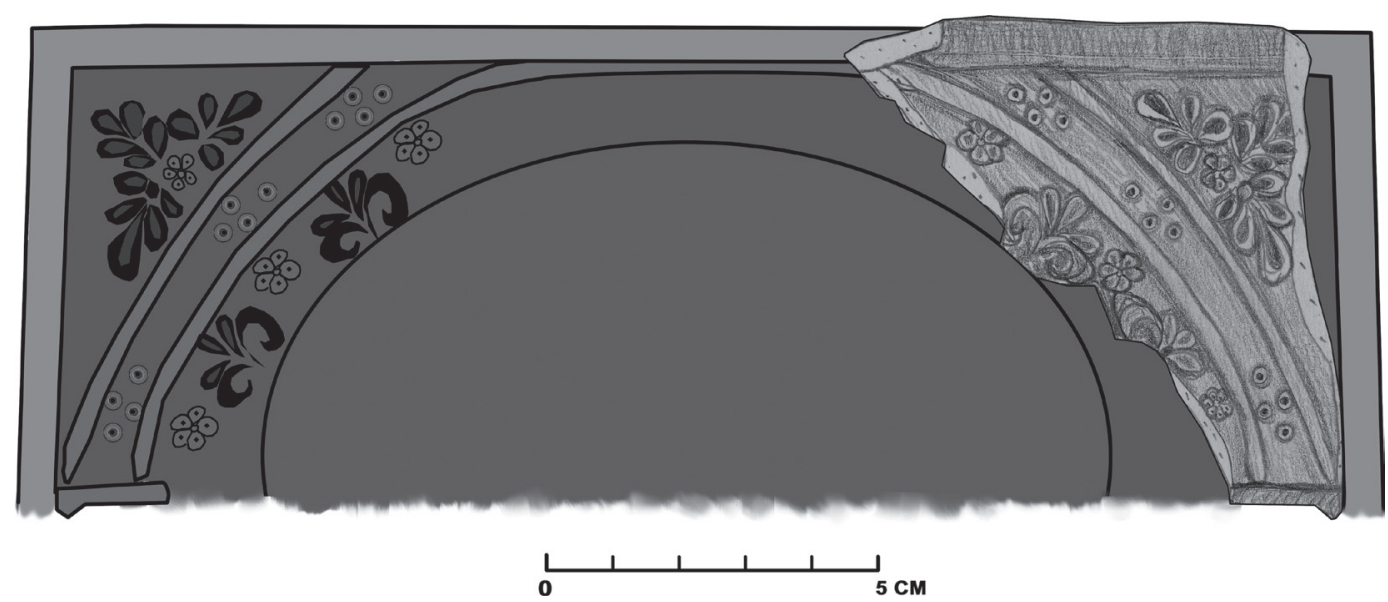

Fig. 7. A frame-reconstruction of Group 2 using Cat. No. 4 


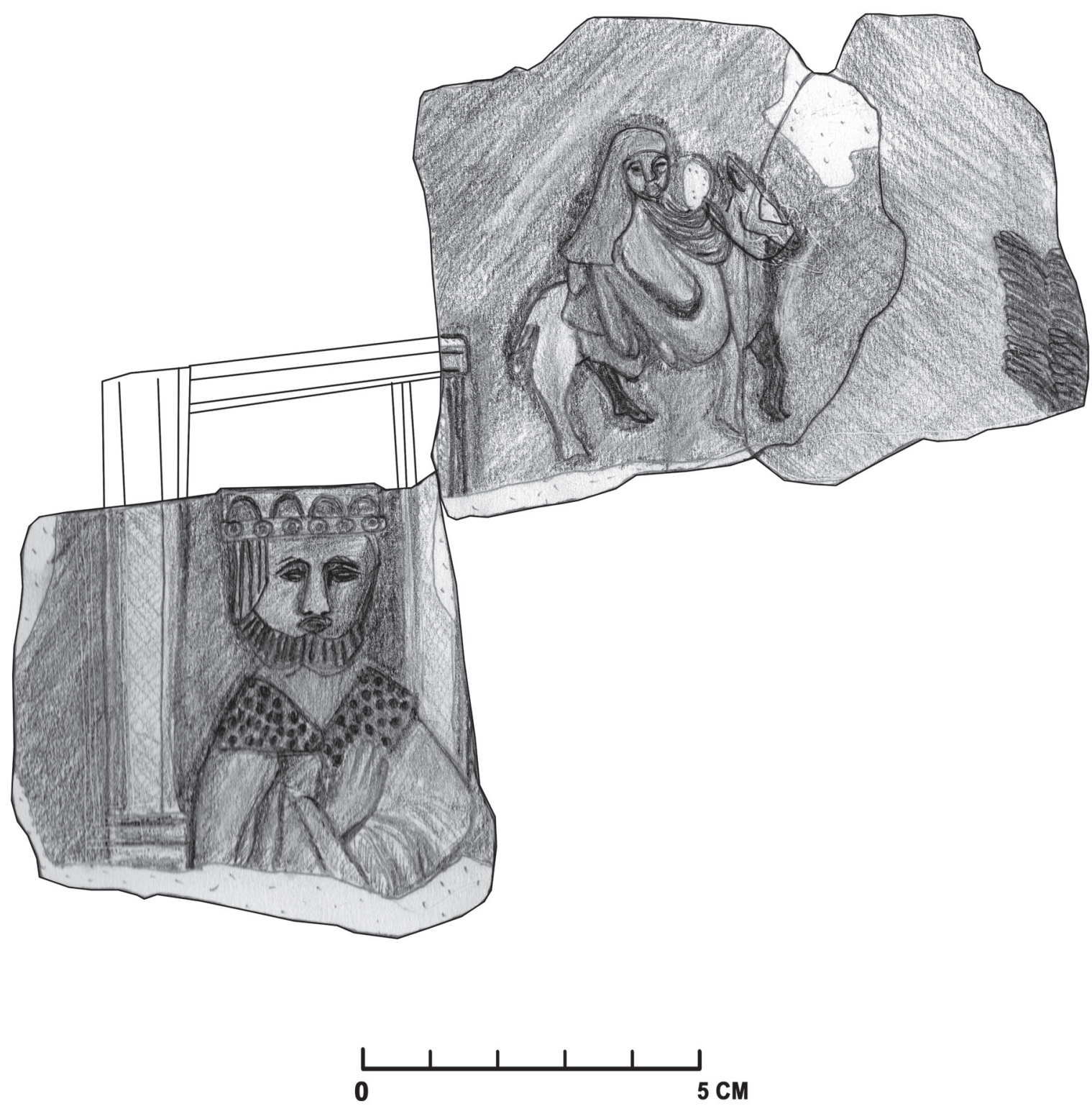

Fig. 8. A part-reconstruction of the Massacre of the Innocents - Flight to Egypt tile of Group 2

enough space between Herod and the palm tree to place another figure. This would also explain the rather odd positioning of the group within the composition. ${ }^{30}$

The scene on Cat. No. 7 can be identified as The Resurrection. ${ }^{31}$ The armoured man in the corner is a sleeping soldier; the rectangular structure is Jesus' tomb with its lid half-open. The other figure is Christ himself, stepping forward, lifting his hand to blessing. Although a rather small portion of the picture is intact, it can be seen from the

${ }^{30}$ This practice was not uncommon by the production of ceramic objects. See for example the fragment of a so called Preuningvase with the scene of the Resurrection from Györ, where the sitting soldiers are almost as big as the standing Jesus. (G. TomKA: Egy re- liefdíszes délnémet kancsó a 16. század közepéről - A relief ornamented South German jug from the $16^{\text {th }}$ century. Arrabona 44/1 [2006] 569, 575, Fig. 1-3).

${ }^{31}$ Matthew XXVIII, $2-4$. 
soldier's Landsknecht-like clothing ${ }^{32}$, as well as from the mould maker's attempt to apply perspective on the positioning of the sarcophagus that the composition was Renaissance. It follows a pretty wide spread type of the late $15^{\text {th }}-16^{\text {th }}$ centuries, observable on many paintings and engravings, including the various 'Passion' series of Albrecht Dürer and Lucas Cranach the Elder. ${ }^{33}$ As their works were highly popular and used in the earliest prints of religious publications, their scenes have very often served as models for other artists. The closest parallel concerning the image on the tile is the woodcut of H. L. Schäufelein from Nuremberg, which was an illustration for the book of U. Pindler, entitled 'Speculum passionis domini nostri Jhesu Christi, 1. Ausg. 1507'. The soldier laying his head on his hand, the opened lid of the sarcophagus and Jesus' flapping mantle are all identical. ${ }^{34} \mathrm{On}$ the other hand some details, such as the exact stance and clothing of the armoured man, the placing of the tomb or the richly pleated drapery of Christ's cloak are simplified. These modifications could have been applied by the further copying of the original picture or by the making of the mould.

It is also notable that the soldier has no face, while on the piece Cat. No. 7 Herod and the Virgin Mary have both finely outlined expressions, apparently shaped after the moulding. It is possible that the soldier - being a less important character - did not get such attention from the master or the original composition was misinterpreted, as he turns the back of his head towards the onlooker on the Schäufelein- and some of the Dürer-engravings. Another option is that the maker of the Pápa-tiles was not the moulds' creator; he just used them and could not recognise all of the details that required further work.

Only one type of stove tiles is known from Hungary, which depicts the life of Christ in such manner. It has two groups with almost the same depictions, one with smaller tiles from the Esztergom castle and some fragments of larger tiles from the upper castle of Visegrád, attributed to a South German workshop (probably Straubing) and dated to $1595-1605 .{ }^{35}$ It can be observed however, that the fragments from Pápa, though quite good quality pieces, have a less detailed and not as professional design as the aforementioned ones. As the Massacre of the Innocentsscene is present in both series it is also clear that they did not use the same original images. ${ }^{36}$

Group 3 (Cat. No. 8; Fig. 16)

Material and base form: Two adjoining fragments of one rectangular cornice tile with short thrown body ${ }^{37}$ belong here. It was fired to a light, reddish yellow colour. It contains very small, white and reddish inclusions and little mica. It was covered by a quite good quality green glaze, which is lighter than by Group 2, on white engobe. The rear wall is somewhat curved.

Production and usage traces: The back of the tile is not sooty, but remains of the clay plastering are visible on both sides, thus it is sure that the tile was built in a stove.

Image: The tile had framing only on the longer side from which the upper one is intact. It shows a simple, profiled shape. The detail of a human figure can be seen in the image area from the foot to the waist. He or she wears a pointed shoe or stocking. A hand can be seen pulling up the character's clothing. As it is proportionally bigger than the foot, it could belong to another person as well, but it is more probable that only one individual is depicted on the tile. It is most likely a dancing scene (it occurs sometimes on pane tiles that the image is rotated by $90^{\circ}$ ), ${ }^{38}$ but a laying figure in a more sensual context is not impossible either.

${ }^{32}$ For similar attires see for example the woodcut illustrations in the autobiographical work of Emperor Maximilian Habsburg I (1459-1519), Der Weißkunig: http://commons.wikimedia.org/wiki/ Category:Wei\%C3\%9Fkunig?uselang=de (Downloaded: 05.12.2014.)

${ }^{33}$ For example: A. Dürer: Die Kupferstichpassion, 18 Bll. (http://www.virtuelles-kupferstichkabinett.de/index. php?currentWerk=87\&); Die kleine Holzschnittpassion (http://www. virtuelles-kupferstichkabinett.de/index.php?currentWerk=347\&); Die große Passion (http://www.virtuelles-kupferstichkabinett.de/index. php?currentWerk=767\&)

L. Cranach the Elder: Die Auferstehung (1509) (http://www. virtuelles-kupferstichkabinett.de/index.php?currentWerk=1649\&).
M. Schongauer: Auferstehung Christi (1470-1491) (http:// www.virtuelles-kupferstichkabinett.de/index.php?currentWerk=1384\&). All in the collections of the Herzog Anton Ulrich Museum (Braunschweig, D) Lugt 291-291a. Downloaded: 03.12.2014.

${ }^{34}$ Herzog Anton Ulrich Museum (Braunschweig, D). V 5076, 19. (http://www.virtuelles-kupferstichkabinett.de/index. php?currentWerk=1563\& Downloaded: 03.12.2014)

${ }^{35}$ Holl 1993, 286-287. Kocsis 2014, 363-365.

${ }^{36}$ Kocsis 2014, 352, Fig. 6/1.

${ }^{37}$ Roth HeEge 2012, 283.

${ }^{38}$ Holl-Voit 1963, Abb. XIII, Taf. 22. 
Interpretation and parallels: Only a few cornice tiles are published with figural decoration in Hungary. Some pieces from Buda and Esztergom belong to the same group, called the 'Genrebild-Ofen' by Imre Holl, dated to the end of the $15^{\text {th }}$ century. ${ }^{39}$ The piece from Pápa is related to them only in being a cornice tile and its profane theme, the dimensions, the forming, the glazing all differ significantly. ${ }^{40}$ Lying female figures can be seen on the cornice tiles from the Ónod castle and Sárospatak, which belong to the so called 'group of virtues', dated to the $16^{\text {th }}$ century. They depict a mythological scene or moralizing story and do not show much likeliness to the fragments from Pápa ${ }^{41}$

Lastly, one tile is known from the town of Košice (SK), which depicts a sleeping knight. It is dated to the beginning of the $16^{\text {th }}$ century and has similar dimensions, composition and green glaze to Cat. No.8, but while this figure wears a renaissance outfit, the pointed leg covering on the Pápa piece aims to the fashion of the late Gothic era. ${ }^{42}$

\section{CONCLUSIONS}

As we can see, the 14 fragments from the pit and its surroundings belong to three distinct groups in terms of their material, shaping, glazing, firing and iconography. As their dimensions also vary, they were probably parts of three different stoves.

Group 1 consists of unglazed, grey, square shaped panel and perhaps corner tiles depicting Samson's fight with the lion from the Old Testament. The image's outlining has no identifiable $16^{\text {th }}$ century model; it seems that an earlier composition was somewhat refreshed for the latest fashion. It has no known parallels from the Hungarian Transdanubia or from the neighbouring Austrian territories, but the similar pieces from Transylvania show the popularity of the topic and the need of actualising it. ${ }^{43} \mathrm{It}$ is possible that these rather simple, unglazed objects were made locally. We have data about the clay workers of the town from the middle ages to the $20^{\text {th }}$ century. ${ }^{44}$

The fragments of Group 2 belong to a series of rectangular and square shaped panel tiles with architectural framing, depicting scenes of Jesus Christ's life. Their themes and composition seem to be connected only indirectly to styles of the known Austrian and South German workshops, but they also show clearly the German and North Italian Renaissance artists' influences - who have designed the illustrations for the most widely read religious and profane prints of the era ${ }^{45}$ The Pápa fragments' layout is of similar quality, but their composition is somewhat inferior compared to the known tiles of this type from Hungary (Esztergom, Visegrád, Sopron, Eger). ${ }^{46}$ Some possibly related tile fragments of the same age were found in the nearby castle of Ugod, depicting the emperor Ferdinand Habsburg I (1503-1564) with his wife and an architectural detail. ${ }^{47}$ Concerning this and the rather similar framefragment from Wiener Neustadt, it should be worth examining the tiles of the nearby urban centres, especially of Györ and Sopron. The rich material of these cities is almost fully unknown and there is plenty of information regarding their citizens' connections to the inhabitants of Pápa. ${ }^{48}$

There are no known parallels to the mysterious cornice tile of Group 3. It seems to be an earlier, late 1400s type, based on the clothing of the person, but it is obvious that a popular model could be used further. Yet it shows no similarity to the $15^{\text {th }}$ century stove tiles excavated in the nearby village of Külsővat that have possibly belonged to the manor house of a local nobleman. ${ }^{49}$ (Esztergom).

${ }^{39}$ Holl-Voit 1963, 34-39, Abb. XIII (Buda); Taf. 22

${ }^{40}$ I would like to thank Eszter Kovács for the possibility to examine the fragments of the 'Genrebild-Ofen' from Buda in the collection of the Budapest History Museum.

${ }^{41}$ G. TOMKA: 16. századi kályhacsempék az ónodi vár ásatásából III. Erények, hősök, emberevők. (Sixteenth-century stove tiles from the excavations at Ónod Castle III. Virtues, heroes, cannibals.) In: Gy. Terei-Gy. Kovács-Gy. Domokos-Zs. Miklós-M. Mordovin (eds.): Várak nyomában. Tanulmányok a 60 éves Feld István tiszteletére. Budapest 2011, 279, 281, Fig. 2. 4., 282, Fig 3.1-2.

42 J. ChOVANEC-K. DANKó-I. FelD-E. TAMÁs: A gótikától a habánokig. Od gotiky po habánov. Kályhacsempék Abaúj, Sáros és Zemplén megyékből. Kachlice z bývalej Abovskej, Šarǐsskej a Zemplínskej župy. [Stove Tiles from Abaúj, Sáros and Zemplén Counties. Exhibition catalogue.] Sárospatak, 1996, 26, Fig. 4., 53, Kat. No. 36.
U. LEHNART: Kleidung und Waffen der Spätgothik. Teil III.: 14201480. Wald-Michelbach 2005, 33.

${ }^{43}$ GrUiA 2009, 237.

${ }^{44}$ KolLÁth 2010-2013, 155.

${ }^{45}$ Holl 1993, 266-291.

${ }^{46}$ Kocsis 2014; Holl 1993, 266-291.

${ }^{47}$ S. MithaY: Az ugodi vár feltárásának eredményei (Die Burg von Ugod). Pápai Múzeumi Értesítő 1 (1988) 60, 61, Abb. 8/2, 6 .

${ }^{48}$ L. GECSÉNYI: Adatok Pápa szerepéhez a 16. században a Rába-menti tájegységben [The role of Pápa in the $16^{\text {th }}$ Century in the Rába-Region]. In: I. Hermann (ed.): Tanulmányok Pápa város történetéből 2. Pápa 1996, 44-46.

${ }^{49}$ G. ILON-T. SABJÁN: 15. századi cserépkályhák Külsővatról (Kachelöfen im Külsővat aus dem 15. Jahrhundert). Ház és Ember 5 (1989) 64-83, 86. 
As we can see there are not any fully matching pieces with the tiles of Pápa at the moment. This is almost surely because of the low number of published finds from the region.

However their themes, models and layout fit perfectly within the $16^{\text {th }}$ century general Middle European fashion of stove designs, which is further supported by their quite well datable archaeological context. ${ }^{50}$ The Reformation movements and the spread of printed books induced a thorough change in the tastes and thinking of literate people, nobility and citizens alike. Circles of religious interest have shifted and widened, thus more obscure Old Testament scenes and heroes could appear in the applied arts, while previously used motives, such as Samson, could gain even more popularity. ${ }^{51}$ Besides the increasing needs of the customers, the opportunity to copy woodcuts and engravings has also made it easier for the mould makers to use more intricate compositions and tell more complex stories, such as the life of Jesus on their stoves. ${ }^{52}$ Although in her recent research, Ana-Maria Gruia could not find a direct connection between the usage of certain stove tiles and the religion of their owners in the former territory of the Hungarian Kingdom, it should be noted that Pápa was an outstanding centre of Reformation movements in the region, hence they could be more aware of new fashions and currents of thought..$^{53}$ (Although the not too shy move of the figure on Cat. No. 8 indicates that the

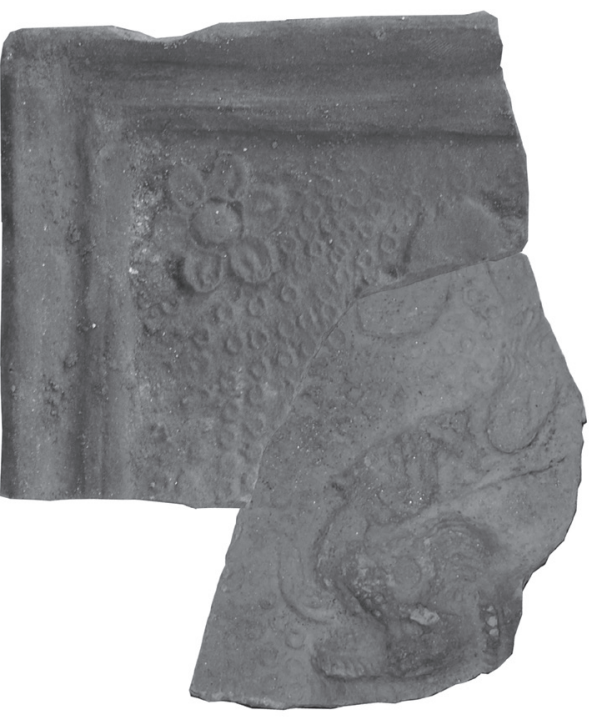
townsfolk had a less pious approach to life as well.) We have no idea who the proprietors of these stoves may have been, but it is quite sure that they were heating the buildings of the main square, most possibly the Fachwerk-houses surrounding the pit, where their fragments have been found. They show distinctly the inhabitants' up-to-date tastes and that they had the demand and the means to purchase rather high quality objects. Their buyers were citizens of a quickly growing, buzzing market town, until the inevitable disasters of the Long Turkish War have got to them. Although the ruins had been levelled and the settlement rebuilt, Pápa has never reached the same economical peak as in its heyday in the $16^{\text {th }}$ century and as far as we know, the people would have no longer bought new figural stove tiles for their houses on the Main Square anymore.

\section{CATALOGUE}

\section{Group 1}

Cat. No. 1 (Fig. 5; Fig. 6; Fig. 9)

Number of fragments: 2 (The frame fragment is not accessible at the moment, but it is without doubt that they match.)

Fragment type: Upper left corner of the frame and part of the image area of a square shaped panel tile with short thrown body.

Image: The frame is rather simple, profiled; its height shrinks towards the central field. The background is decorated by slightly elevated point-circles and a flower in the upper left corner. In the centre a bearded man is visible wearing a long sleeved jacket with ruffled cuffs, opening the mouth of a lion. The lion's tongue is stuck out. A tendril-like shape can be seen above the man's head, which can be part of a feathered hat or the hair of the main character.

Other: Textile impressions on the rear wall.

Dimensions: circa $10 \times 10 \mathrm{~cm}$

Wall width: $0.7 \mathrm{~cm}$

${ }^{50}$ Roth HeEge 2012, 271. Holl 1993, 266.

${ }^{51}$ GRUIA 2009, 237.

${ }^{52} \mathrm{H}$. Rosmanitz: Grafische Vorlagen und Umsetzung. In: Roth HEEge 2012, 65-66.

${ }^{53}$ GruiA 2009, 238. Zs. KövY: A református egyház szerepe Pápa életében (1520-tól napjainkig) (Die Rolle der reformierten Kirche im Leben der Stadt Pápa). In: A. Kubinyi (ed.): Tanulmányok Pápa város történetéből. Pápa 1994, 393-397. 


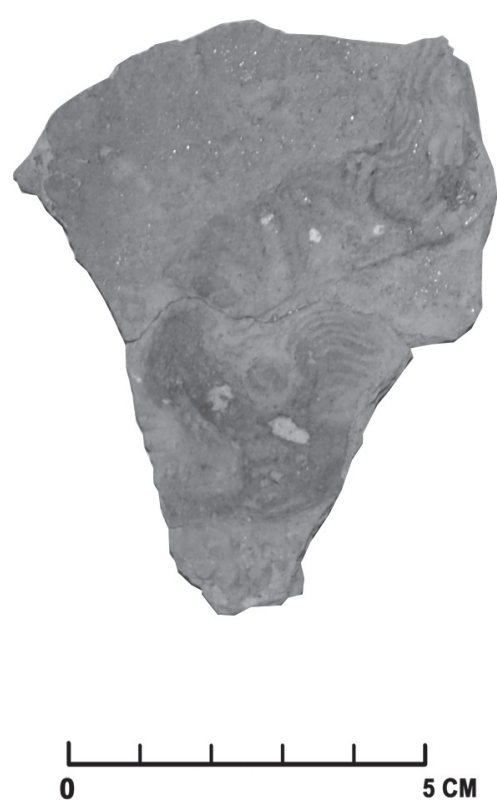

Fig. 10. Cat. No. 2
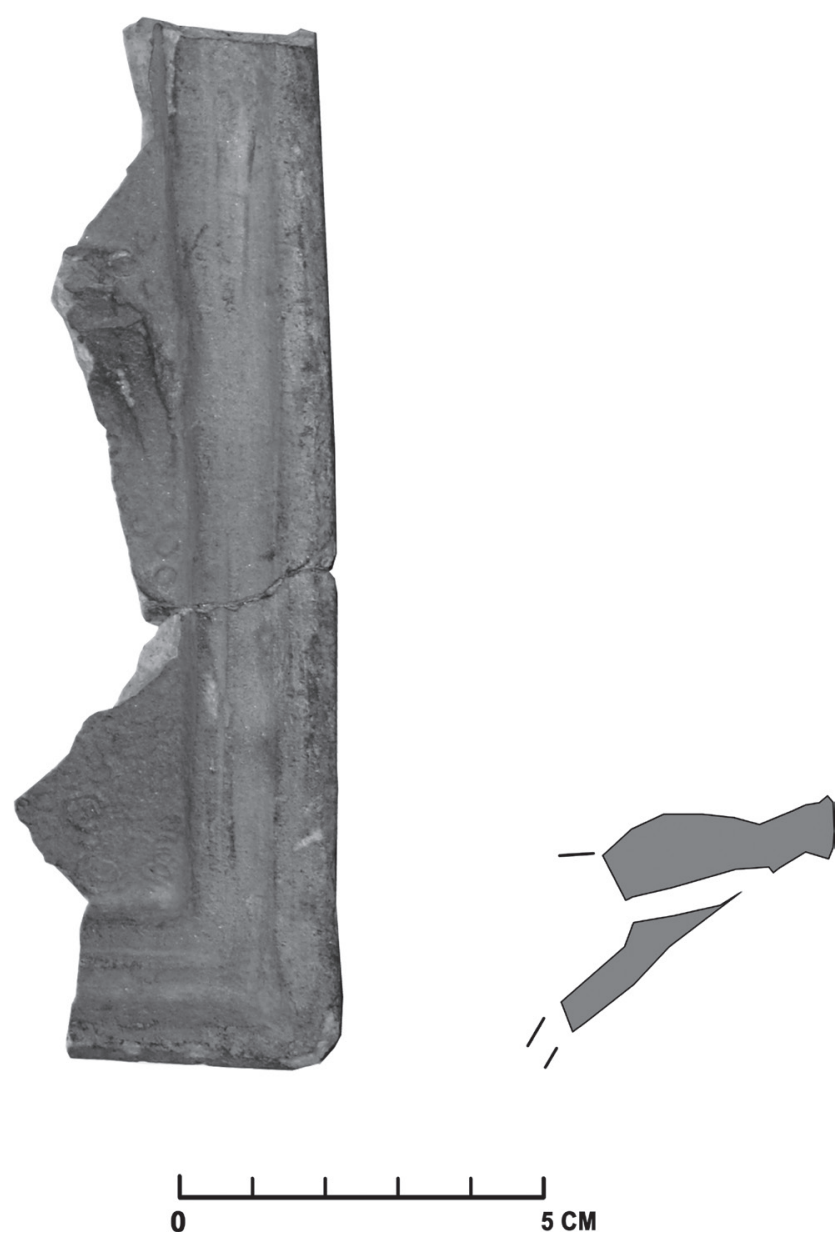

Fig. 11. Cat. No. 3

Cat. No. 2 (Fig. 6; Fig. 10)

Number of fragments: 2

Fragment type: Part of the image area of a square shaped panel tile.

Image: The background is decorated by slightly elevated point-circles. It is a bit smudged. A bearded man wearing a long sleeved jacket with ruffled cuffs, opening the mouth of a lion, with a tendril-like shape above his head. The scene is exactly the same as on Cat. No. 1 .

Other: Textile impressions on the rear wall.

Dimensions: $8.6 \times 6.8 \mathrm{~cm}$

Wall width: $0.8 \mathrm{~cm}$

Cat. No. 3 (Fig. 4; Fig. 6; Fig. 11)

Number of fragments: 2

Fragment type: Right edge and lower right corner with a small part of the image area of a square shaped panel or corner tile with short thrown body.

Image: The frame is rather simple, profiled; its height shrinks towards the central field. The background is decorated by slightly elevated point-circles. A smudged flower can be seen in the lower right corner. A leg with a more or less star shaped attachment (a spur) is visible in the middle.

Other: The rear wall is cut out and perforated.

Dimensions: $16 \times 5.1 \mathrm{~cm}$

Height (by the cut out wall section): $2.6 \mathrm{~cm}$

Wall width: $0.6-0.8 \mathrm{~cm}$ 


\section{Group 2}

Cat. No. 4 (Fig. 7; Fig. 12)

Number of fragments: 1

Fragment type: Outer and inner frame of a rectangular panel tile with short thrown body.

Image: Simple, elevated outer frame, the inner frame forms a multiply partitioned architectural arch, decorated by rosettes, pointcircles and acanthus leaves.

Dimensions: $8.7 \mathrm{~cm} \times 8.7 \mathrm{~cm}$

Height: $5 \mathrm{~cm}$

Wall width: $0.7 \mathrm{~cm}$

Cat. No. 5 (Fig. 8; Fig. 13)

Number of fragments: 2

Fragment type: Left and upper edge of the image area of a rectangular panel tile with short thrown body.

Image: Crowned king in fur-collared mantle, with a rectangular composition in the background. There is a mounted female figure above him, to the right, holding something in her shroud.

Other: The adjoining surface of the two fragments is too small for gluing them together.

Dimensions: $6.8 \times 7.3 \mathrm{~cm} ; 6.6 \times \times 7 \mathrm{~cm}$

Wall width: $0.7 \mathrm{~cm}$

Cat. No. 6 (Fig. 8; Fig. 14)

Number of fragments: 1

Fragment type: Upper edge of the image area of a rectangular panel tile with short thrown body.

Image: The front part of the same mounted figure as by Cat. No. 5 with part of a palm tree to the right.

Other: The glaze of this piece is heavily damaged.

Dimensions: $6.9 \times 6.5 \mathrm{~cm}$

Wall width: $0.8 \mathrm{~cm}$

Cat. No. 7 (Fig. 15)

Number of fragments: 1

Fragment type: Lower left part of the image area of a rectangular panel tile with short thrown body.

Image: An armoured man sitting, leaning on his hand, with his elbow propped against his knee. A rectangular structure is formed in the background with a framed lid. The lid's handle is visible. Part of a man on the right side of the fragment, holding up his hand, with his middle and forefinger stretched the others bent. Part of his mantle is visible.

Other: The glaze on this piece is slightly damaged.

Dimensions: $10.3 \times 6.2 \mathrm{~cm}$

Wall width: $0.8 \mathrm{~cm}$

\section{Group 3}

Cat. No. 8 (Fig. 16)

Number of fragments: 2

Fragment type: Upper frame and image area of a cornice tile with short thrown body.

Image: A simple, profiled frame, underneath part of a human figure (female?). His/her leg is bent; a hand (possibly his/her own) is pulling up his/her richly draped clothing.

Other: Rests of the clay plastering are visible on both sides of the fragment.

Dimensions: $8.3 \times 11.3 \mathrm{~cm}$

Height: $6.4 \mathrm{~cm}$

Wall width: $0.6 \mathrm{~cm}$ 


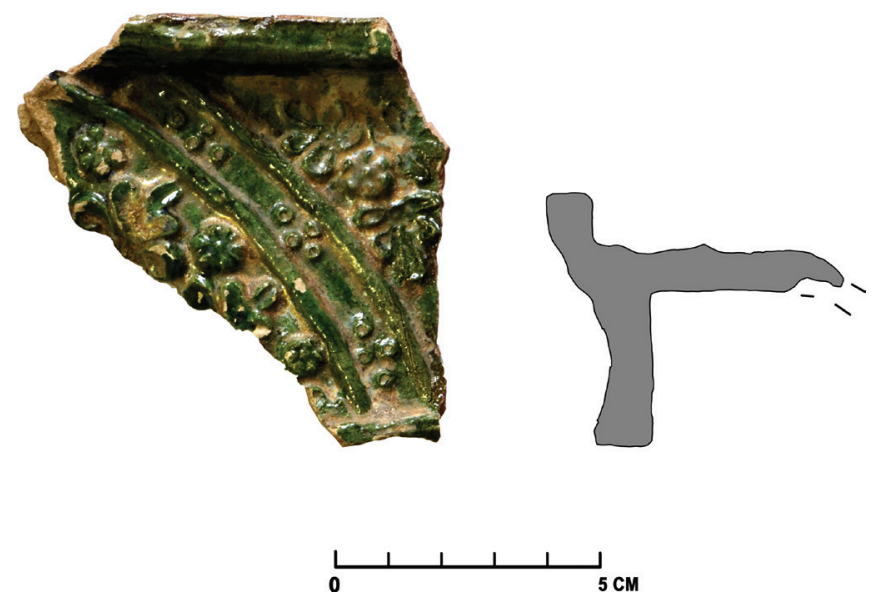

Fig. 12. Cat. No. 4

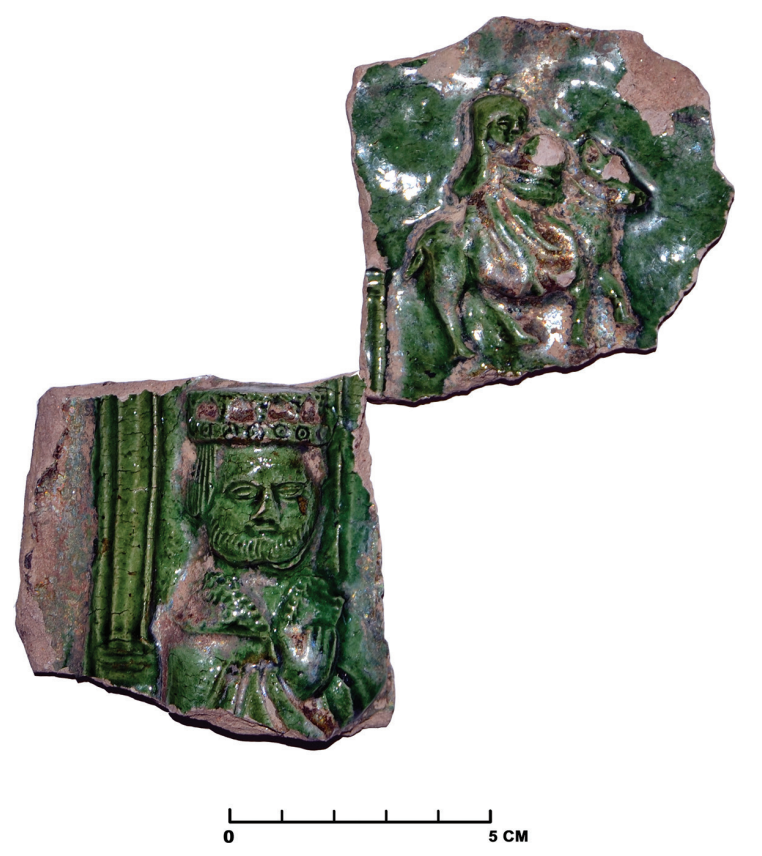

Fig. 13. Cat. No. 5

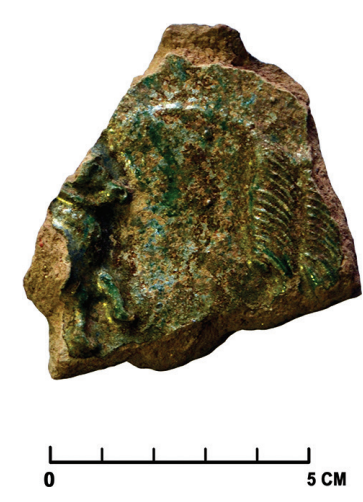

Fig. 14. Cat. No. 6 

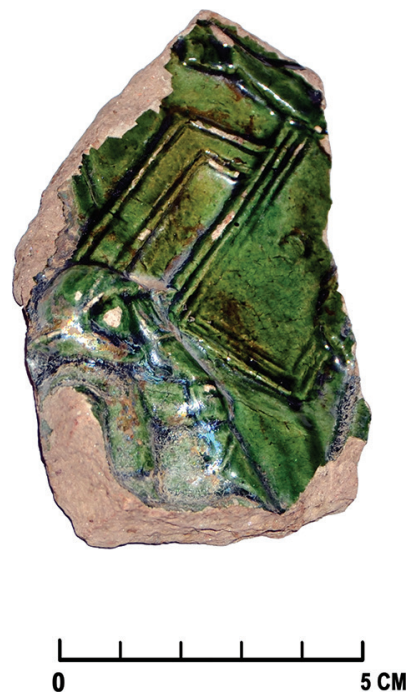

Fig. 15. Cat. No. 7

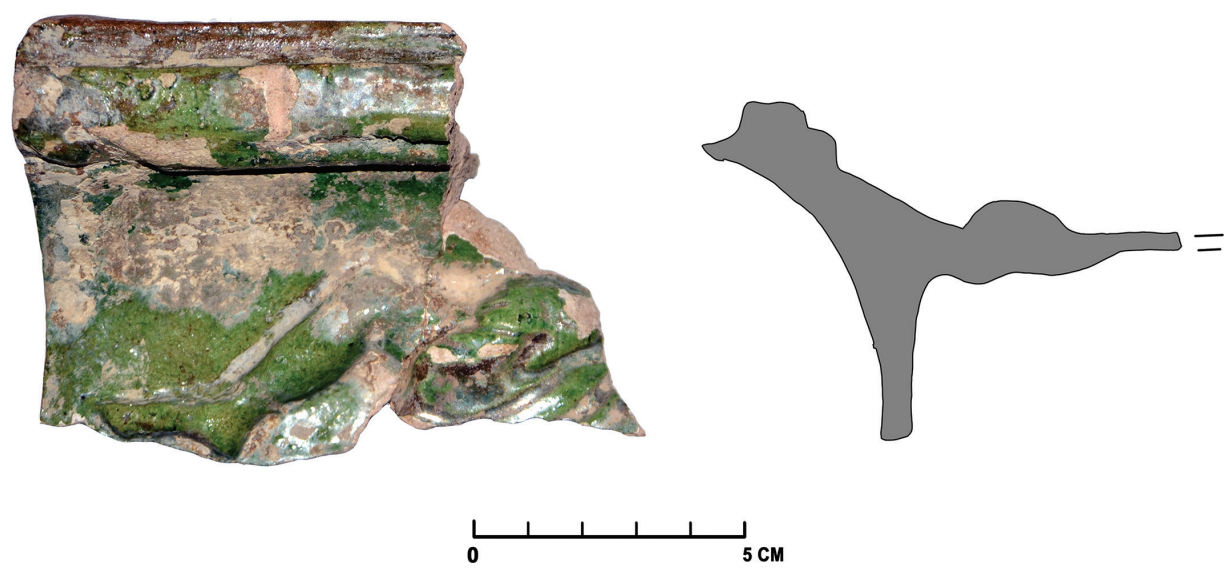

Fig. 16. Cat. No. 8

REFERENCES

BRYCH 2004

GRUIA 2009

Holl-VoIT 1963

HOLL 1993

KoCsIS 2014

KoLLÁTH 2010-2013

MORDOVIN 2013

$=\mathrm{V}$. BRYCH: Kachle doby gotické, renesanční a raně barokní. Výběrový katalog. Národního muzea v Praze [Stove tiles of Gothic, Renaissance and Early-Baroque period. Exhibition catalogue, National Museum in Prague]. Praha 2004.

= A. M. GRUIA: Religious Representations on Stove Tiles from the Medieval Kingdom of Hungary. $\mathrm{PhD}$ thesis submitted to Central European University, Department of Medieval Studies. Budapest 2009.

= I. HoLL - P. VoIT: Alte ungarische Ofenkacheln. Budapest 1963.

= I. HoLL: Mittelalterliche Ofenkacheln in Ungarn. 5: Renaissance-Öfen. ActaArchHung 45 (1993) 247-299.

= E. Kocsis: Jézus életét bemutató kályha Esztergomból, a XVI. század végéröl (Ofen mit Darstellungen des Lebens Jesu aus der Burg von Esztergom/Gran vom Ende des 16. Jahrhunderts). ArchÉrt 138 (2013) 345-366.

= Á. KolláTH: 16-19. századi kerámiatípusok Pápán (Keramiktypen in Pápa aus dem 16.-19 Jahrhundert). ComArchHung 2010-2013 (2014) 151-183.

= M. Mordovin: A 15-17. századi távolsági kereskedelem régészeti emlékei Pápán (The archaeological traces of the $15^{\text {th }}-17^{\text {th }}$ centuries distance cloth-trade in Pápa). In: M. Varga (ed.): Fiatal Középkoros Régészek IV. Konferenciájának tanulmánykötete. A Kaposvári Rippl-Rónai Múzeum Közleményei 2. Kaposvár 2013, 267-282. 
Roth HEEGE 2012

SZAKÁLY 1994

SZVATH 2012
= E. Roth HeEge: Ofenkeramik und Kachelofen. Typologie, Terminologie und Rekonstruktion. Schweizer Beiträge zur Kulturgeschichte und Archäologie des Mittelalters 39. Basel 2012.

= F. SZAKÁLY: Pápa a török korban (Pápa während der Türkenzeit, 1526-1686). In: A. Kubinyi (ed.): Tanulmányok Pápa város történetéből. Pápa 1994, 77-124.

= M. Szvath: Pápa, Fő tér. In: J. Kisfaludi (ed.): Régészeti kutatások Magyarországon/Archaeological Investigations in Hungary 2010. Budapest 2012, 321-322. 